\title{
Correction to: Self-sampling for human papillomavirus testing among rural young women of KwaZulu-Natal, South Africa
}

\author{
J. N. Mbatha ${ }^{1,2^{*}}$, H. N. Galappaththi-Arachchige ${ }^{3,4}$, A. Mtshali ${ }^{1}$, M. Taylor ${ }^{5}$, P. D. Ndhlovu ${ }^{6}$, E. F. Kjetland ${ }^{3,5}$, \\ M. F. D. Baay ${ }^{3,7}$ and Z. L. Mkhize-Kwitshana ${ }^{1,8}$
}

\section{Correction to: BMC Res Notes (2017) 10:702}

https://doi.org/10.1186/s13104-017-3045-3

Following publication of the original article [1], one of the authors reported that his name had been spelled incorrectly. It should be Galappaththi-Arachchige, not Galapaththi-Arachchige.

The original article has been corrected.

\section{Author details}

${ }^{1}$ School Laboratory Medicine and Medical Science, University of KwaZuluNatal, Durban, South Africa. ${ }^{2}$ Department of Biomedical and Clinical Technology, Durban University of Technology, PO Box 1334, Durban 4000, South Africa. ${ }^{3}$ Norwegian Centre for Imported and Tropical Diseases, Department of Infectious Diseases, Oslo University Hospital, Oslo, Norway. ${ }^{4}$ Faculty of Medicine, University of Oslo, Oslo, Norway. ${ }^{5}$ Discipline of Public Health, Nelson R Mandela School of Medicine, University of KwaZulu-Natal, Durban, South Africa. ${ }^{6}$ Claybrook Center, Imperial College London, London, UK.

${ }^{7}$ Laboratory of Cancer Research and Clinical Oncology, University of Antwerp, Antwerp, Belgium. ${ }^{8}$ Department of Biomedical Sciences, Mangosuthu University of Technology, Durban, South Africa.

\section{Publisher's Note}

Springer Nature remains neutral with regard to jurisdictional claims in published maps and institutional affiliations.

Received: 16 February 2018 Accepted: 16 February 2018 Published online: 26 February 2018

\section{Reference}

1. Mbatha JN, Galappaththi-Arachchige HN, Mtshali A, Taylor M, Ndhlovu PD, Kjetland EF, Baay MFD, Mkhize-Kwitshana ZL. Self-sampling for human papillomavirus testing among rural young women of KwaZulu-Natal, South Africa. BMC Res Notes. 2017;10:702. https://doi.org/10.1186/s1310 4-017-3045-3.

\footnotetext{
*Correspondence: nonhlanhlam@dut.ac.za

${ }^{2}$ Department of Biomedical and Clinical Technology, Durban University

of Technology, PO Box 1334, Durban 4000, South Africa

Full list of author information is available at the end of the article
} provided you give appropriate credit to the original author(s) and the source, provide a link to the Creative Commons license, and indicate if changes were made. The Creative Commons Public Domain Dedication waiver (http://creativecommons.org/ publicdomain/zero/1.0/) applies to the data made available in this article, unless otherwise stated. 